\title{
ASSESSMENT OF DATA ON STUDYING PERSONAL - PROFESSIONAL SELF- DETERMINATION OF STUDENTS OF AGROENGINEERING PROFILE
}

Elena Zorina, Olga Chudnova

Stavropol State Agrarian University, Russia

zeb26@mail.ru

\begin{abstract}
Data of pilot study on studying the features of formation of personal and professional selfdetermination of students of agroengineering higher education institution are provided in the article and the analysis of data on indicators of motivation to enter a higher education institution, the system of valuable orientations, social mental sets and features of the system of interpersonal relations are presented. During the empirical research the complex of the methods, which have allowed to realize the objectives, to provide reliability of results and validity of conclusions has been used; the main area of application of the results received during the research was their application in the experimental program of psychological maintenance of the process of personal and professional self-determination of students of university of an agrarian profile.
\end{abstract}

Keywords: personal and professional self-determination, motivation of entering a higher education institution, system of valuable orientations, social mental set, features of the system of interpersonal relations.

\section{Introduction}

Transition of the higher education to the paradigm "education during all life" is characterized by strengthening of student orientation. Modern higher education is designed to work for the future and owing to this mission it has to advance the system of requirements imposed "here and now".

In the conditions of dynamically changing realities of the modern world traditional and habitual valuable norms and stereotypes cannot serve as a reference point for the developing personality using the considerable efforts for search of the course of life. For realization of so complex challenge it is necessary to form special valuable and semantic installations to life, to the experience, to build the personal position dictating the need for judgment of an event number of the past and the future. In this regard studying of features of formation of personal and professional self-determination of students of different profiles and directions plays a special role.

Despite the significant amount of the operations devoted to questions of professional selfdetermination unresolved are questions, both about an entity, and about correlation of personal and actually professional components of self-determination. There is obvious a need of development of ad hoc methods and methods of a psychological maintenance and support of the developing personality, which would create conditions for development of the ability to predict and comprehend the subsequent stages of the life and to create a professional image I.

At various stages of professional formation of specialists of profile higher education institutions inevitably there are psychological problems caused by the contents and features of the process of his professional and personal self-determination. Comprehensive psychological support of the process of professional formation, which has to be carried out with support of the personal potential of the student, can play a positive role in overcoming these problems, achievement of tops of self-realization.

The solution of a number of theoretical and practical questions of vocational training of students of an agricultural orientation restrains the number of contradictions between:

- requirement of modern agricultural enterprises for experts of modern technological and administrative methods, capable to realization, and a possibility of profile higher education institutions to meet these requirements;

- need to realize comprehensive psychological support of the process of personal and professional self-determination of students of an agroengineering profile and an insufficient readiness of scientific-theoretical and practical bases of this activity;

- requirement to introduce the new content of psychological ensuring the educational process at the higher school and an insufficient readiness of psychological technologies of this process.

Relevance of the research is caused by insufficiency of researches of psychological maintenance of formation of the expert of an agrarian profile, his personal and actually professional components of self-determination in the course of training in higher education institution. The research objective was 
studying of the features of psychological maintenance of personal and professional self-determination of students of an agroengineering profile in the course of high school training. As research questions the following provisions were considered by us:

- psychological escort of students at a grade level in higher education institution causes optimization of personal and professional self-determination of the student, formation of an image of the successful professional, his valuable orientations and vital meanings;

- personal and professional self-determination of the student of agroengineering higher education institution is a dynamic process determined by the specifics of professional activity, set of psychological characteristics of the student and the environment of his professional development;

- process of personal and professional self-determination of students is connected with change of the valuable and motivational sphere of the personality and formation of an image of the world including values of the natural world and careful attitude to him.

\section{Materials and methods}

Experimental studying of the features of formation of personal and professional selfdetermination of students of agroengineering higher education institution during training in higher education institution was carried out on the basis of the Stavropol State Agricultural University. 217 students have participated in a research. From them 107 people in "Mechanization of agriculture". And 110 people in "Agronomics". The presented groups of examinees of these specializations differ in the direction and the nature of activity and the respective contents of training. Future engineers of agriculture, first of all, have to seize knowledge of devices, working processes and adjustments of farm vehicles; bases of electrification and automation of agricultural production; bases of performance of technological operations and rules of quality control of work at cultivation of crops. The respective content of vocational education is more submitted by technical disciplines.

At the second stage 113 examinees were examined. They have been divided into two groups experimental and control. It should be noted that inclusion in this or that group happened individually and on educational groups, but at the same time the need of completing of control and experimental groups comparable among themselves was considered. The number of these groups has turned out almost identical that is defined by that volume of work, which needed to be carried out with examinees of both groups at the 3rd investigation phase. Thus, the experimental group has included 57 examinees, and the control - 56.

For all examinees the following indicators were studied:

- motivation of entering a higher education institution;

- system of valuable orientations;

- social mental sets;

- features of the system of interpersonal relations;

- image of the world as a system of ideas of the world around.

During the empirical research the complex of the methods, which have allowed to realize the objectives to provide reliability of results and validity of conclusions, has been used: observation, poll, interview, testing forming an experiment, methods of the qualitative and quantitative analysis of empirical data. According to the program of the empirical research the group of psychodiagnostic techniques has been applied: T. Leary's test, technique "Valuable orientations" of M. Rokich, version of the Incomplete Offers test for research of an image of the world of students. The research took place in several stages. The first stage included understanding of a problem situation, statement of a research problem, definition of the purposes and tasks, promotion of a hypothesis, analysis of scientific literature on the designated problem, formation of theoretical and methodological approaches to a research and the choice of experimental base. At the second stage the experimental work was carried out: psychological diagnostics of adaptation of students to training in higher education institution, self-determination indicators are studied (valuable and motivational orientations). 


\section{Results and Discussion}

On the basis of processing and the analysis of the diagnostic data obtained during the stating stage of the pilot study the following generalizations have been made.

Studying and the analysis of structure of valuable orientations of the first-year students of agronomical and engineering faculties have shown that generally at students the activity focused type of professional self-determination is characterized by recognition of the values "active life" and "interesting work" at decrease in the importance of the values of "efficiency", "freedoms, independence", "creativity" prevailing.

At a stage of adaptation of students to training conditions the structure of valuable orientations of students is characterized by flexibility, instability, big dynamism.

Values of self-updating are insufficiently expressed in this studied selection of students. Despite recognition of the value "active life" at students, it acts as means of achievement of the goals as sense of duty, discipline, accuracy, which to a less extent characterize a subject position of the person and confirm the low level of personal and professional self-determination of students.

The students studying at offices of agricultural mechanization and agronomics differ in orientation of social mental sets. At future agronomists orientation is to the result and altruism, at future engineers it is more expressed to the process and egoism (Fig. 1).

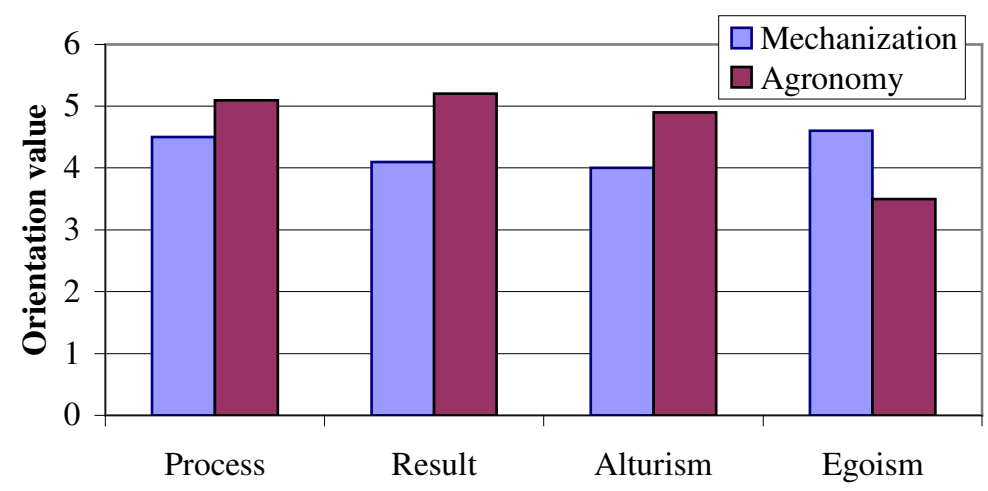

Fig. 1. Comparative characteristics of student orientations on vectors "process - result", "altruism - egoism"

The social mental sets concerning orientation "freedom - the power" and "work - money" at the first-year students of agronomical and agroengineering offices have a disharmonious profile.

However, the orientation profiles of the designated groups differ in directivity: future agronomists are more oriented on the value of freedom and work, and future engineers are characterized by a bigger directivity on the value freedom and money.

The study of a professional image of the world showed that the generalized image of the world of the first-year students of agroengineering higher education institution is characterized by bigger inconsistency, amorphy of perception of temporal perspective, bigger idealization of own selfrealization and feeble structuredness of a professional image I.

The results of the stating stage of the experiment defined the directivity and informative filling of psychological attending of personal and professional self-determination of students of agroengineering higher education institution at a grade level. As the leading strategy of the organization of the psychology and pedagogical help to students - to future agronomists in personal and professional selfdetermination at a stage of high school training the practical-oriented strategy of attending was defined.

Psychology and pedagogical attending are based on the integrated system concept, defining not only its entity, but also the direct organization of this process. All subdivisions of higher education institution and the faculty participate in implementation of psychology and pedagogical attending: lecturers of profile disciplines, departments, tutors, laboratory of pedagogics and psychology of health. In a type of absence in higher education institution of psychological service, basic functions on adaptation and optimization of students are executed by laboratory of pedagogics and psychology of 
health. Psychological attending of personal and professional self-determination of students represented a three-stage process: initial, main and final.

At the initial stage of training, the most important is process of adaptation of the first-year students to higher education institution. Optimization of the adaptive process of the first-year students includes a package of measures, directed as to action of optimization of the factors defining success of adaptation and correction of separate violations and to increase in indices of productivity, lowering of psychological and psychophysiological cost in case of operation of the main engines of adaptation.

At the main stage of psychology and pedagogical maintenance of personal and professional selfdetermination of students a bigger accent is put to work on formation of a professional image I and to development of career orientations taking into account that at this stage self-determination crisis is observed.

As activities of formation of personal reflection, expansion of ideas of future profession, acquisition of practical skills and abilities, design of future career are defined.

In work on formation of a positive professional image of students of an agrarian profile we recognized that idea of a profession consists of three aspects: professional (knowledge of the subject of the content of work, working conditions, requirements imposed by a profession on the person); personal (orientation to own opportunities and abilities and their improvement); social (awareness of the subject on such aspects of a profession as the public importance, salary, prospects of professional growth, social and economic working conditions and the objective need for experts of the chosen profession).

At the final stage of psychology and pedagogical maintenance the great value is attached to development of career orientation to strengthening of the author's position in this question. The author's position is responsibility and sensibleness in realization of personal resources and creative potential in the context of professional activity (Fig. 2).

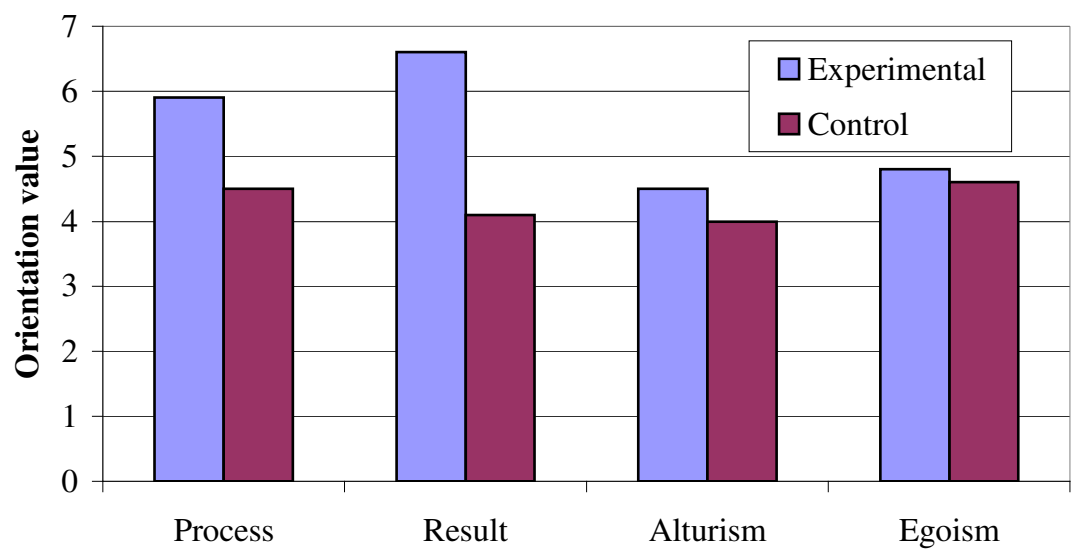

Fig. 2. Orientation of orientation profiles before implementation of the program of psychological maintenance

Psychological maintenance of personal and professional self-determination of students of an agroengineering profile took place during all stages of the experiment. At the final stage control diagnostics on studying of dynamics of changes of the valuable and semantic structure of students in the course of training in higher education institution, changes of motivational orientation, orientation of the interpersonal relations and the image of the world was carried out.

The results of the check experiment have shown that in the experimental group the rank of the values connected with their future professional activity has raised: such values as "interesting work", "beauty of the nature and art (experience fine in the nature and in art)", "productive life (fullest use of the opportunities, forces and abilities)" occupy a higher rank now.

It should be noted that values, significant for young men, "love (spiritual and physical proximity with darling)", "presence of good and loyal friends" have risen by higher positions. We consider this result very important as these data show a possibility of a combination of values of interpersonal and business relations and demonstrate unity of personal and professional self-determination. 
Thus, it is possible to track that the maintenance of the common and professional interests at students of the experimental group extends, amplifies the need for personal and professional selfaffirmation.

There were considerable changes in the orientation of social mental sets in the experimental group in comparison with the control. At the experimental group increase in the values on the vector "result" and "process" is observed. The students with big understanding treat the future professional activity and own professional effectiveness. Orientation of future agronomists to the result says that they have a desire and readiness to achieve results in the activity, despite the barriers and difficulties, which are found on their way. In the experimental group the change is much steadier. The most significant distinctions are observed in the "result" and "process" parameters. The importance of distinctions was estimated by means of the Student's t-criterion that confirms reliability of the received result.

We consider important the result revealed on the scale "work". In both groups the tendency to increase in the indicator on this scale is observed, but in the experimental group this dynamics is expressed stronger, and as a result at the third stage the difference (estimated by the Student's tcriterion) is statistically significant.

Carrying out a cycle of the correctional developing occupations with students about their ideas has resulted in positive changes. They began to perceive themselves as capable and ready to cooperation, but at the same time paying attention in interaction and to the interests, to a lesser extent inclined to renounce them for the sake of recognition by people around "at any cost".

By the results of control diagnostics at the students, who have passed the system of the correctional developing occupations, changes in the image of the world and the character of the selfdescriptions relating to the professional sphere are observed, they carry mainly positive shade. An important feature is differentiation of the professional image I and big substantial fullness of the professional image I students.

\section{Conclusions}

By the results of the conducted research and its theoretical judgment we have formulated the following conclusions:

- professional self-determination is inseparably linked with personal self-determination. In this regard, features of the structure and regularity of professional and personal self-determination need to be considered at early stages of professionalizing;

- axiological orientation of training assuming the appeal to valuable, personal and semantic aspects of educational professional activity of students. Development of humanistic maintenance of the system of values and meanings of future professional activity, development of ecological consciousness acts as a necessary part of their vocational training;

- valuable and moral component of professional self-determination at a grade level in higher education institution as the qualitative characteristic of this process defines the type of professional self-determination of students and influences its efficiency through the change of the semantic component. Performing the function of professional self-determination, it gives sense of the carried-out activity, allocates to value the purpose and provides values to means for achievement of the designated purposes;

- process of personal and professional self-determination of students of agroengineering higher education institution is connected with formation corresponding to the type of a profession of the valuable and motivational attitude towards it chosen by them and to the world. Work on ensuring professional self-determination has to consider the image of the world inherent in this type of professions, which is coordinated with the main characteristics of the professional orientation of the personality;

- for professions of an agroengineering profile the image of the world is focused on the ecological relation to the world around - recognition of the value of the natural world and the careful relation to it is adequate. The sphere of this relation naturally joins also other people, the relation to whom at the professional profile is based on the ability to understand foreign points of view, to respect other tastes, customs, and habits connected with development of empathy, keenness in interpersonal relationships; 
- formation of personal and professional self-determination at the final stage of training, on condition of organized psychological assistance, is connected with harmonization of the structure of valuable orientations, their bigger definiteness, stability and adequacy to the process of further personal and professional development.

\section{References}

1. Алефиренко Н.Ф. Лингвокультурология: ценностно-смысловое пространство языка (Ligvoculturology: value and meaning of language space): учебное пособие / Н. Ф. Алефиренко. - М.: Флинта: Наука, 2010. - 284 с. (in Russian).

2. Библер В.С. От наукоучения к логике культуры. Два философских введения в двадцать первый век. (From stydy of science to logics of culture. Two philosophy introductions into twenty first century.) - М.: Политиздат, 1990. - 413 c. (in Russian).

3. Зимняя И.А. Педагогическая психология. (Pedagogical psychology) - М.: Логос, 2002. - 383 c. (in Russian).

4. Garsia O. Billingual Education in the $21^{\text {st }}$ Century: A Global Perspective, Wiley-Blackwell.

5. Smeby, J.-C., Heggen K. Coherence and the development of professional knowledge and skills. Journal of Education and Work. Volume 27. Issue 1, 2014, pp. 71-91.

6. Иовайша Л.А. Основы подготовки учащихся к выбору профессии ( The basis of preparing students to choose profession), авто-реф. докт. дисс. - Вильнюс, 1990. - 158 с. (in Russian).

7. Anastasi A. Psychological testing. (7th ed). New York Macmillan, 1996.

8. Flavell J.H., Miller P.H., Miller S.A. Cognitive development (3rd ed.). Englewood Cliffs, NJ: Prentice Hall, 1993.

9. Gleitman H. Basic Psychology.WW Norton, 1992.

10. Hall C.S., Lindsey G. et al. Introduction to Theories of Personality.Wiley and Sons, 1995.

11. Shostrom E. An inventory for the measurement of self-actualization // Educational and psychological measurement. 1996. V. 24. № 2. pp. 207-218. 